\title{
Halopelagius inordinatus gen. nov., sp. nov., a new member of the family Halobacteriaceae isolated from a marine solar saltern
}

Correspondence
Heng-Lin Cui
cuihenglin@ujs.edu.cn

\author{
Heng-Lin Cui, ${ }^{1}$ Xin-Yi Li, ${ }^{1}$ Xia Gao, ${ }^{1}$ Xue-Wei Xu, ${ }^{2}$ Yu-Guang Zhou, ${ }^{3}$ \\ Hong-Can Liu, ${ }^{3}$ Aharon Oren ${ }^{4}$ and Pei-Jin Zhou ${ }^{3}$
}

\author{
${ }^{1}$ School of Food \& Biological Engineering, Jiangsu University, Zhenjiang 212013, PR China \\ ${ }^{2}$ Second Institute of Oceanography, State Oceanic Administration, Hangzhou 310012, PR China \\ ${ }^{3}$ Institute of Microbiology, Chinese Academy of Sciences, Beijing 100101, PR China \\ ${ }^{4}$ Institute of Life Sciences, and the Moshe Shilo Minerva Center for Marine Biogeochemistry, The \\ Hebrew University of Jerusalem, Jerusalem 91904, Israel
}

Two extremely halophilic archaea, strains RO5-2 ${ }^{\top}$ and RO5-14, were isolated from Rudong marine solar saltern in Jiangsu, China. Cells of the two strains were pleomorphic, motile and stained Gram-negative. Colonies were red-pigmented. Strains RO5-2 ${ }^{\top}$ and RO5-14 were able to grow at $20-50{ }^{\circ} \mathrm{C}$ (optimum $37^{\circ} \mathrm{C}$ ), at 2.6-4.8 M NaCl (optimum 3.4-3.9 M NaCl), at 0.03$0.7 \mathrm{M} \mathrm{MgCl}_{2}$ (optimum 0.5 $\mathrm{M} \mathrm{MgCl}_{2}$ ) and at $\mathrm{pH}$ 5.5-8.0 (optimum $\mathrm{pH}$ 6.5-7.0). Cells lyse in distilled water and the minimal $\mathrm{NaCl}$ concentration to prevent cell lysis was $12 \%(\mathrm{w} / \mathrm{v})$. The major polar lipids of the two strains were phosphatidylglycerol, phosphatidylglycerol phosphate methyl ester and two major glycolipids chromatographically identical to sulfated mannosyl glucosyl diether (S-DGD-1) and mannosyl glucosyl diether (DGD-1). The 16S rRNA gene sequences of strains RO5-2 ${ }^{\top}$ and RO5-14 showed 93.4-93.8\% similarity to the closest cultivated relative, Halosarcina pallida. The DNA G + C content of strains RO5-2 ${ }^{\top}$ and RO5-14 was $61.0 \mathrm{~mol} \%$ and 59.9 mol\%, respectively. The DNA-DNA relatedness between strains RO5-2 ${ }^{\top}$ and RO5-14 was $86.0 \%$. The phenotypic, chemotaxonomic and phylogenetic properties suggest that strains RO5- $2^{\top}$ and RO5-14 represent a novel species in a new genus within the family Halobacteriaceae, for which the name Halopelagius inordinatus gen. nov., sp. nov. is proposed. The type strain is RO5-2 ${ }^{\top}$ (=CGMCC $\left.1.7739^{\top}=J C M 15773^{\top}\right)$.
Extremely halophilic archaea that grow optimally in media containing $1.5-4.5 \mathrm{M} \mathrm{NaCl}$ are widely distributed in all kinds of hypersaline environments as well as in saline microniches in some non-hypersaline environments (Oren, 2006; Savage et al., 2007, 2008). These micro-organisms are classified within the family Halobacteriaceae, the single family described within the order Halobacteriales. The identification of the genera and species belonging to the

Abbreviations: DGD-1, mannosyl glucosyl diether; PG, phosphatidylglycerol; PGP-Me, phosphatidylglycerol phosphate methyl ester; PGS, phosphatidylglycerol sulfate; S-DGD-1, sulfated mannosyl glucosyl diether.

The GenBank/EMBL/DDBJ accession numbers for the $16 \mathrm{~S}$ rRNA gene sequences of strains $\mathrm{RO5}^{\top} \mathrm{2}^{\top}$ and $\mathrm{RO5}-14$ are EU887284 and FJ944013, respectively.

A scanning electron micrograph of strain $\mathrm{RO} 5-2^{\top}$, a phase-contrast micrograph of strain RO5-14, thin-layer chromatograms and a maximum-parsimony phylogenetic tree based on 16S rRNA gene sequences of strains RO5-2 ${ }^{\top}, \mathrm{RO} 5-14$ and some other haloarchaea are available with the online version of this paper. family Halobacteriaceae is currently based on a polyphasic approach (Oren et al., 1997). At the time of writing, the family Halobacteriaceae accommodated 27 recognized genera (Oren et al., 2009), members of which inhabit both thalassohaline and athalassohaline environments.

Marine solar salterns, the typical thalassohaline hypersaline environments located in tropical and subtropical areas worldwide, are artificial shallow ponds for the production of common salt from seawater. There are more than 100 marine solar salterns built along the $18000 \mathrm{~km}$ coastline of Eastern China. Some of these coastal salterns have been long-term targets for the study of halophilic archaeal resources (Cui et al., 2007; Xu et al., 2007). In this paper, we report on the isolation and characterization of two novel halophilic archaeal strains that represent a novel species in a novel genus of the family Halobacteriaceae.

Rudong solar saltern $\left(32.2699^{\circ} \mathrm{N} 121.3999^{\circ} \mathrm{E}\right)$ is an artificial marine solar saltern located in Jiangsu Province, China. At the time of sampling, 28 March 2008, Rudong 
solar saltern had been off-production for less than 1 year after more than 30 years flourishing, and plenty of salt granules could be found in the saline soil of the saltern. To isolate halophilic archaea, soil samples from the solar saltern were collected (using a sterile steel spoon) into sterile $50 \mathrm{ml}$ plastic tubes with screw caps. The tubes were carried back to the laboratory at room temperature. The neutral oligotrophic haloarchaeal medium (NOM) used for the isolation procedure was modified according to the DBCM2 medium from the online Halohandbook (DyallSmith, 2008) and contained the following ingredients $\left(1^{-1}\right)$ : yeast extract (Oxoid), $0.05 \mathrm{~g}$; fish peptone (Sinopharm Chemical Reagent Co.), $0.25 \mathrm{~g}$; sodium pyruvate, $1.0 \mathrm{~g}$; $\mathrm{KCl}, 5.4 \mathrm{~g} ; \mathrm{K}_{2} \mathrm{HPO}_{4}, 0.3 \mathrm{~g} ; \mathrm{CaCl}_{2}, 0.25 \mathrm{~g} ; \mathrm{NH}_{4} \mathrm{Cl}, 0.25 \mathrm{~g}$; $\mathrm{MgSO}_{4} \cdot 7 \mathrm{H}_{2} \mathrm{O}, 26.8 \mathrm{~g} ; \mathrm{MgCl}_{2} .6 \mathrm{H}_{2} \mathrm{O}, 23.0 \mathrm{~g} ; \mathrm{NaCl}, 184.0 \mathrm{~g}$ ( $\mathrm{pH}$ adjusted to 7.0-7.2 with $1 \mathrm{M} \mathrm{NaOH}$ solution). The medium was solidified with $2.0 \%$ agar. One gram of soil was suspended in $9 \mathrm{ml}$ of liquid NOM medium, serially diluted with the same medium and then plated onto NOM agar plates. The plates were incubated in the dark at $37^{\circ} \mathrm{C}$ for at least 8 weeks in sealed plastic bags. The plate with 50 to 100 colonies was selected for picking the single colonies designated strains $\mathrm{RO} 5-2^{\mathrm{T}}$ and RO5-14. To ensure purity, a single colony of each strain was restreaked twice onto NOM plates. The strains were routinely grown aerobically at $37^{\circ} \mathrm{C}$ in NOM-1 medium containing $\left(1^{-1}\right)$ : yeast extract, $0.2 \mathrm{~g}$; fish peptone, $0.2 \mathrm{~g}$; sodium pyruvate, $2.0 \mathrm{~g}$; sodium lactate, $2.0 \mathrm{~g} ; \mathrm{KCl}, 5.4 \mathrm{~g} ; \mathrm{K}_{2} \mathrm{HPO}_{4}, 0.3 \mathrm{~g} ; \mathrm{NH}_{4} \mathrm{Cl}, 0.5 \mathrm{~g}$; $\mathrm{MgSO}_{4} \cdot 7 \mathrm{H}_{2} \mathrm{O}, 20.0 \mathrm{~g} ; \mathrm{NaCl}, 200.0 \mathrm{~g}$ (pH 7.0-7.2).

Phenotypic tests were performed according to the proposed minimal standards for the description of novel taxa in the order Halobacteriales (Oren et al., 1997). The type strains Haloferax volcanii CGMCC $1.2150^{\mathrm{T}}$, Haloferax elongans JCM $14791^{\mathrm{T}}$, Halogeometricum borinquense JCM $10706^{\mathrm{T}}$, Halosarcina pallida BZ256 ${ }^{\mathrm{T}}$ and Haloplanus natans JCM $14081^{\mathrm{T}}$ were selected as reference strains in positive and negative testing. Cell morphology and motility in exponentially growing liquid cultures were examined using a Leica microscope equipped with phase-contrast optics (model DM LB2). For scanning electron microscopy examination, $0.5 \mathrm{ml}$ samples were fixed overnight at $4{ }^{\circ} \mathrm{C}$ by adding glutaraldehyde to a final concentration of $5 \%$ $(\mathrm{v} / \mathrm{v})$. A $5 \mu \mathrm{l}$ sample was smeared on a polylysine-coated coverslip and air-dried. The coverslip was then serially dehydrated in 40, 70, 90 and $100 \%$ (v/v) ethanol solutions (10 min at each stage), critical-point dried, mounted on a specimen stub, sputter-coated with gold and viewed in a JEOL JSM-7001F scanning electron microscope. Minimal salt concentration to prevent cell lysis was tested by suspending washed cells in sterile saline solutions containing $\mathrm{NaCl}$ from 0 to $15 \%(\mathrm{w} / \mathrm{v})$, and the stability of the cells was detected by light microscopic examination.

The Gram stain was performed by following the method outlined by Dussault (1955). Most miscellaneous biochemical tests and nutritional tests were performed as described and cited by Bardavid et al. (2007). Briefly, growth and gas formation with nitrate as electron acceptor were tested in
$10 \mathrm{ml}$ stoppered tubes completely filled with liquid growth medium to which $5 \mathrm{~g} \mathrm{NaNO}_{3} \mathrm{l}^{-1}$ had been added and containing an inverted Durham tube. The formation of nitrite was monitored colorimetrically. Anaerobic growth in the presence of L-arginine and $5 \mathrm{~g} \mathrm{DMSO}{ }^{-1}$ was tested in completely filled $10 \mathrm{ml}$ stoppered tubes. Starch hydrolysis was determined on NOM agar plates supplemented with $2 \mathrm{~g}$ soluble starch $\mathrm{l}^{-1}$ and detected by flooding the plates with Lugol's iodine solution. Gelatin hydrolysis was performed by growing colonies on NOM agar plates amended with $0.5 \%(\mathrm{w} / \mathrm{v})$ gelatin and flooding the plates with Frazier reagent after growth was established. Esterase activity was detected as outlined by Gutiérrez \& González (1972). Tests for catalase and oxidase activities were performed as described by Gonzalez et al. (1978). Production of $\mathrm{H}_{2} \mathrm{~S}$ was tested by growing the isolates and reference strains in a tube with NOM liquid medium supplemented with $0.5 \%(\mathrm{w} / \mathrm{v}) \mathrm{Na}_{2} \mathrm{~S}_{2} \mathrm{O}_{3}$; a filter-paper strip impregnated with lead acetate was used for $\mathrm{H}_{2} \mathrm{~S}$ detection (Cui et al., 2007). To test for growth on single carbon sources, fish peptone and sodium pyruvate were omitted from the NOM medium and the compound to be tested was added at a concentration of $5 \mathrm{~g} \mathrm{l}^{-1}$. After 7-10 days of cultivation, the turbidity of the cultures was compared with those without added carbon sources. Sensitivity to antimicrobial agents was performed as described by Gutiérrez et al. (2008).

Cells of strains RO5-2 ${ }^{\mathrm{T}}$ and RO5-14 were motile and pleomorphic (rods and irregular cocci, see Supplementary Fig. S1 available in IJSEM Online) when grown in NOM-1 liquid medium. Cells stained Gram-negative and colonies were red-pigmented. Strains RO5-2 ${ }^{\mathrm{T}}$ and RO5-14 were able to grow at $20-50{ }^{\circ} \mathrm{C}$ (optimum $37{ }^{\circ} \mathrm{C}$ ), at $2.6-4.8 \mathrm{M} \mathrm{NaCl}$ (optimum $3.4-3.9 \mathrm{M} \mathrm{NaCl}$ ), at $0.03-0.7 \mathrm{M} \mathrm{MgCl}_{2}$ (optimum $0.5 \mathrm{M} \mathrm{MgCl}_{2}$ ) and at $\mathrm{pH}$ 5.5-8.0 (optimum $\mathrm{pH}$ 6.5-7.0). Cells lyse in distilled water and the minimal $\mathrm{NaCl}$ concentration to prevent cell lysis was $12 \%(\mathrm{w} / \mathrm{v})$. Both strains produced indole from tryptophan and did not hydrolyse gelatin, Tweens 20, 40, 60 and 80, starch and casein. They were able to grow in defined and complex media; D-glucose, D-mannose, D-galactose, D-fructose, maltose, sucrose, lactose, glycerol, D-sorbitol and acetate as carbon sources yielded the best growth. Acid was produced during growth on carbohydrates. The two strains differed in the utilization of single carbon sources for growth; strain $\mathrm{RO} 5-2^{\mathrm{T}}$ used succinate, L-malate and fumarate, but strain RO5-14 did not. More detailed results of phenotypic tests and nutritional features of the two strains are given in the genus and species descriptions.

Genomic DNA from the halophilic archaeal strains was prepared as described by $\mathrm{Ng}$ et al. (1995). The $16 \mathrm{~S}$ rRNA genes were amplified via PCR by using primers $0018 \mathrm{~F}$ and 1518R (Cui et al., 2009). PCR was performed in a thermal cycler (MJ Research PTC-150) for 30 cycles (initial $5 \mathrm{~min}$ denaturing step at $95{ }^{\circ} \mathrm{C} ; 1 \mathrm{~min}$ denaturing at $95{ }^{\circ} \mathrm{C}, 1 \mathrm{~min}$ annealing at $60{ }^{\circ} \mathrm{C}$ and $1.5 \mathrm{~min}$ elongation at $72{ }^{\circ} \mathrm{C}$; final extension step at $72{ }^{\circ} \mathrm{C}$ for $\left.10 \mathrm{~min}\right)$. The PCR products 
were examined on a $1.0 \%(\mathrm{w} / \mathrm{v})$ agarose gel and then cloned into the pEASY-T vector (TransGen Biotech) and transformed into Escherichia coli Mach1 cells. Eight transformants for each strain were randomly picked and sequenced at the Sino-GenoMax Company, Beijing, China, to determine whether the two strains possessed multiple distinct 16S rRNA gene sequences. Multiple sequence alignments were performed by using the CLUSTAL $\mathrm{W}$ program integrated in the MEGA4 software (Tamura et al., 2007). Phylogenetic trees were reconstructed using the neighbour-joining (Saitou \& Nei, 1987) and maximumparsimony (Fitch, 1971) methods in MEGA4. The percentages of replicate trees in which the associated taxa clustered together in the bootstrap test (1000 replicates) were calculated. 16S rRNA gene sequence similarity was calculated by comparison with sequences of related halophilic archaea from the online EzTaxon server (Chun et al., 2007).

Sixteen complete 16S rRNA gene sequences (1472 nt each) of strains RO5-2 $2^{\mathrm{T}}$ and RO5-14 were obtained. Sequence comparisons indicated that both strains have one kind of $16 \mathrm{~S}$ rRNA gene sequence; they are $99.3 \%$ similar to each other. Both strains showed low levels of $16 \mathrm{~S}$ rRNA gene sequence similarity to other members of the family Halobacteriaceae. The most closely related recognized species were representatives of the genera Halosarcina (Halosarcina pallida, 93.4-93.8\% similarity), Haloferax (Haloferax volcanii, 93.2-93.6\% similarity), Halogeometricum (Halogeometricum borinquense, 93.1-93.5\% similarity), Haloquadratum (Haloquadratum walsbyi, 90.4-90.7\% similarity) and Haloplanus (Haloplanus natans, 90.1\% similarity). Phylogenetic analysis using the neighbour-joining algorithm revealed that the two strains distantly clustered with the Haloferax, Haloquadratum, Halogeometricum and Halosarcina clades (Fig. 1). The phylogenetic position was also confirmed in a tree generated using the maximumparsimony algorithm (see Supplementary Fig. S2). The single clade comprising strains $\mathrm{RO} 5-2^{\mathrm{T}}$ and $\mathrm{RO} 5-14$, separated from the genera Haloferax and Haloquadratum, suggests that the two strains represent a novel phylogenetic taxon.
Polar lipids were extracted by using a chloroform/methanol system and analysed by using one- and two-dimensional TLC, as described previously (Kates, 1986). Merck silica gel $60 \mathrm{~F}_{254}$ aluminium-backed thin-layer plates were used in TLC analysis. To detect phospholipids, the plate was subjected to two-dimensional development, with the first solvent of chloroform/methanol/water $(65: 25: 4$, by vol.) followed by the second solvent of chloroform/methanol/ acetic acid/water (85:12:15:4, by vol.), then sprayed with the phosphate stain reagent (Vaskovsky \& Kostetsky, 1968). To detect glycolipids, the plate was subjected to single development in the solvent chloroform/methanol/acetic acid/water $(85: 22.5: 10: 4$, by vol.) and detected by spraying with $0.5 \% \alpha$-naphthol in methanol/water $(1: 1$, $\mathrm{v} / \mathrm{v})$. The plate was then sprayed with sulfuric acid/ethanol $(1: 2, \mathrm{v} / \mathrm{v})$ followed by heating at $150{ }^{\circ} \mathrm{C}$ for $3 \mathrm{~min}$ to detect phospholipids and glycolipids. Strains RO5- $2^{\mathrm{T}}$ and RO5-14 contained phosphatidylglycerol (PG), phosphatidylglycerol phosphate methyl ester (PGP-Me) and two glycolipids chromatographically identical to sulfated mannosyl glucosyl diether (S-DGD-1) and mannosyl glucosyl diether (DGD-1) (Supplementary Fig. S3). The absence of phosphatidylglycerol sulfate (PGS) within this group helps to differentiate the two strains from the member of the genus Haloplanus, which contains PGS (Bardavid et al., 2007). The glycolipid profile sets strains $\mathrm{RO} 5-2^{\mathrm{T}}$ and RO5-14 apart from Halogeometricum borinquense, which possesses a novel non-sulfate-containing glycolipid (MontalvoRodríguez et al., 1998), and the sole member of the genus Haloquadratum, which only contains S-DGD-1 (Burns et al., 2007).

DNA G $+\mathrm{C}$ content of the novel strains was determined by the HPLC method (Mesbah et al., 1989). DNA-DNA hybridization analyses were performed according to the thermal denaturation and renaturation method of De Ley et al. (1970) as modified by Huß et al. (1983). The DNA $\mathrm{G}+\mathrm{C}$ content of strains RO5-2 ${ }^{\mathrm{T}}$ and RO5-14 was 61.0 and $59.9 \mathrm{~mol} \%$, respectively. These values are lower than those of Halosarcina pallida (65.4 mol\%; Savage et al., 2008) and Haloplanus natans (66.2 mol\%; Bardavid et al., 2007), but higher than the values reported for Haloquadratum walsbyi

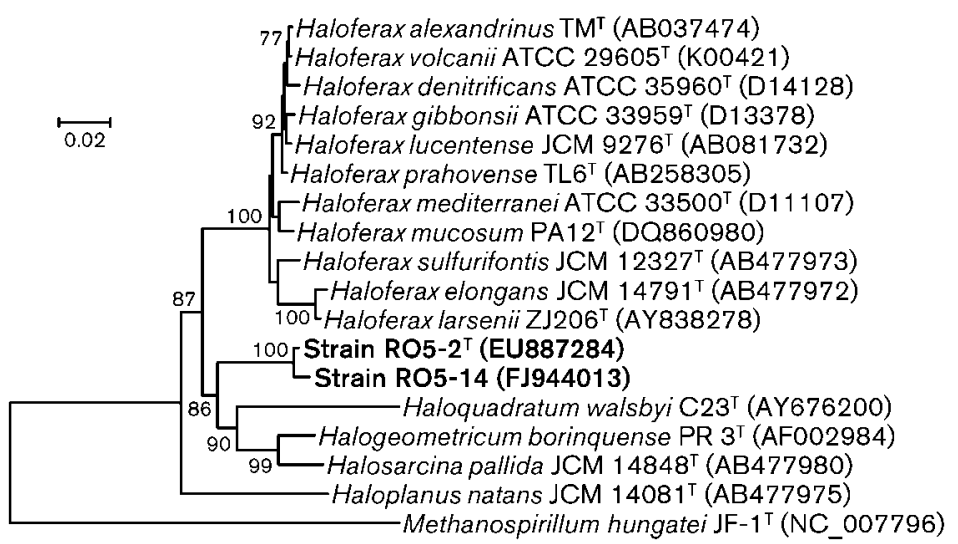

Fig. 1. Neighbour-joining phylogenetic tree based on 16S rRNA gene sequences showing the relationship between strain $\mathrm{RO} 5-2^{\top}$, strain RO5-14 and other close relatives within the family Halobacteriaceae. Bootstrap values (\%) are based on 1000 replicates and are shown for branches with more than $75 \%$ bootstrap support. Bar, 0.02 substitutions per nucleotide position. 
(46.9 mol\%) (Burns et al., 2007) and Halogeometricum borinquense (59.1 mol\%; Montalvo-Rodríguez et al., 1998). The DNA-DNA relatedness between strains $\mathrm{RO} 5-2^{\mathrm{T}}$ and RO5-14 was $86.0 \%$. The data show that the two strains should be classified in the same species, since the generally accepted threshold value to separate two species is $70 \%$ (Stackebrandt \& Goebel, 1994).

In view of the morphological and physiological properties of the new strains, the low levels of $16 \mathrm{~S}$ rRNA gene sequence similarity with other genera within the family Halobacteriaceae and the distinctive components of the polar lipid profiles, we suggest that strains $\mathrm{RO} 5-2^{\mathrm{T}}$ and RO5-14 represent a novel species of a new genus within the family Halobacteriaceae, for which the name Halopelagius inordinatus gen. nov., sp. nov. is proposed. Characteristics that distinguish strains $\mathrm{RO} 5-2^{\mathrm{T}}$ and $\mathrm{RO} 5-14$ from other genera within the family Halobacteriaceae are shown in Table 1.

\section{Description of Halopelagius gen. nov.}

Halopelagius (Ha.lo.pe.la'gi.us. Gr. masc. n. hals halos salt; L. masc. adj. pelagius pertaining to the sea; N.L. masc. n. Halopelagius salt organism from the sea).

Cells are pleomorphic under optimal growth conditions and stain Gram-negative. Aerobic heterotrophs. Cells lyse in distilled water. Oxidase and catalase tests are positive. Temperatures between 20 and $50{ }^{\circ} \mathrm{C}$ support growth. Sugars are metabolized, in some cases with formation of acids. Cells contain PG and PGP-Me, but PGS is absent.
Two main glycolipids are present and chromatographically identical to S-DGD-1 and DGD-1. The genomic DNA $\mathrm{G}+\mathrm{C}$ content is $59.9-61.0 \mathrm{~mol} \%$. The type species is Halopelagius inordinatus. Recommended three-letter abbreviation: $\mathrm{Hpl}$.

\section{Description of Halopelagius inordinatus sp. nov.}

Halopelagius inordinatus (i.nor.di.na'tus. L. masc. adj. inordinatus not arranged, irregular).

Cells are motile, pleomorphic when grown in NOM-1 liquid medium and stain Gram-negative. Colonies on agar plates containing $3.9 \mathrm{M} \mathrm{NaCl}$ are red, elevated and round. Chemo-organotrophic and aerobic. Growth occurs at 20$50{ }^{\circ} \mathrm{C}$ (optimum $37{ }^{\circ} \mathrm{C}$ ), at $2.6-4.8 \mathrm{M} \mathrm{NaCl}$ (optimum 3.4$3.9 \mathrm{M} \mathrm{NaCl}$ ), at $0.03-0.7 \mathrm{M} \mathrm{MgCl}_{2}$ (optimum $0.5 \mathrm{M}$ $\mathrm{MgCl}_{2}$ ) and at $\mathrm{pH}$ 5.5-8.0 (optimum $\mathrm{pH}$ 6.5-7.0). Cells lyse in distilled water and the minimal $\mathrm{NaCl}$ concentration to prevent cell lysis is $12 \%(\mathrm{w} / \mathrm{v})$. Catalase- and oxidasepositive. Does not grow under anaerobic conditions with nitrate, arginine and DMSO. Nitrate reduction to nitrite is not observed. Nitrite is reduced. $\mathrm{H}_{2} \mathrm{~S}$ is produced from $\mathrm{Na}_{2} \mathrm{~S}_{2} \mathrm{O}_{3}$. Positive for indole formation. Tweens 20, 40, 60 and 80 are not hydrolysed. Negative for caseinase, amylase and gelatinase. The following substrates are utilized as single carbon and energy sources for growth: D-glucose, Dmannose, D-galactose, D-fructose, maltose, sucrose, lactose, glycerol, D-sorbitol, acetate, pyruvate, DL-lactate, succinate, $\mathrm{L}$-malate, fumarate, L-alanine, L-glutamate and L-ornithine. L-Sorbose, D-ribose, D-xylose, starch, D-mannitol, citrate,

Table 1. Differential characteristics between strain $R O 5-2^{\top}$, strain $R O 5-14$ and closely related genera within the order Halobacteriales

Taxa: 1, Strains RO5-2 ${ }^{\mathrm{T}}$ and RO5-14; 2, Haloferax (Allen et al., 2008); 3, Haloquadratum (Burns et al., 2007); 4, Halogeometricum (MontalvoRodríguez et al., 1998); 5, Halosarcina (Savage et al., 2008); 6, Haloplanus (Bardavid et al., 2007). +, Positive; -, negative; UG, unidentified glycolipid. All data was confirmed in the present study.

\begin{tabular}{|lcccccc|}
\hline Characteristic & $\mathbf{1}$ & $\mathbf{2}$ & $\mathbf{3}$ & $\mathbf{4}$ & $\mathbf{5}$ & $\mathbf{6}$ \\
\hline Cell shape & Pleomorphic & Pleomorphic & Squares & Pleomorphic & Cocci & Pleomorphic \\
Colony colour & Red & Red to pink & Red to pink & Pink & Pink & Pink \\
Optimum NaCl (M) & $3.4-3.9$ & $1.7-4.3$ & 3.1 & $3.1-4.3$ & 3.1 & 3.0 \\
Optimum temperature $\left({ }^{\circ} \mathrm{C}\right)$ & 37 & $32-53$ & 45 & 40 & 30 & 40 \\
Optimum pH & $6.5-7.0$ & $7.0-7.5$ & 7.0 & 7.0 & 6.5 & 7.0 \\
Anaerobic growth with nitrate & - & $+/-$ & - & + & - & - \\
Catalase activity & + & + & - & + & + & + \\
Oxidase activity & + & $+/-$ & - & + & + & + \\
Indole formation & + & $+/-$ & - & + & + & + \\
Starch hydrolysis & - & $+/-$ & - & - & - & - \\
Gelatin liquefaction & - & $+/-$ & - & + & - & - \\
Glucose used & + & + & - & + & + & + \\
Glycerol used & + & + & - & + & + & - \\
DNA G+C content (mol\%) & 59.9-61.0 & $-59.5-65.3$ & 46.9 & 59.1 & 65.4 & 66.2 \\
Presence of PGS & - & - & - & - & - & + \\
Types of glycolipids present & S-DGD-1, & S-DGD-1, DGD-1 & S-DGD-1 & UG & S-DGD-1, & S-DGD-1 \\
& DGD-1 & & & & DGD-1 & \\
\hline
\end{tabular}


glycine, L-arginine, L-aspartate and L-lysine are not utilized as carbon sources. Sensitive to the following antibiotics ( $\mu \mathrm{g}$ per disc, unless otherwise indicated): rifampicin (5), novobiocin (30), bacitracin (0.04 IU per disc), anisomycin (20) and aphidicolin (20). Resistant to the following antibiotics: erythromycin (15), neomycin (30), chloramphenicol (30), ampicillin (10), penicillin G (10 IU per disc), norfloxacin (10), ciprofloxacin (5), streptomycin (10), kanamycin (30), tetracycline (30), vancomycin (30), gentamicin (10) and nalidixic acid (30). The major polar lipids are PG, PGP-Me, S-DGD-1 and DGD-1. The DNA $\mathrm{G}+\mathrm{C}$ content of the type strain is $61.0 \%$ (as determined by HPLC).

The type strain is RO5-2 ${ }^{\mathrm{T}}$ (=CGMCC $1.7739^{\mathrm{T}}=\mathrm{JCM}$ $\left.15773^{\mathrm{T}}\right)$, and was isolated from the Rudong solar saltern in Jiangsu province, China.

\section{Acknowledgements}

This work was supported by the National Natural Science Foundation of China (no. 30970006), the National Science \& Technology Infrastructure Program of China (no. 2005DKA2120611), a grant from Jiangsu Department of Education (no. 08KJB180002), a startup grant from Jiangsu University (no. 08JDG016) and two scientific training grants for senior students from Jiangsu Department of Education and Jiangsu University. We are grateful to Dr Mostafa S. Elshahed and Ms Kristen N. Savage for kindly providing the type strain, Halosarcina pallida $\mathrm{BZ}^{256^{\mathrm{T}}}$.

\section{References}

Allen, M. A., Goh, F., Leuko, S., Echigo, A., Mizuki, T., Usami, R., Kamekura, M., Neilan, B. A. \& Burns, B. P. (2008). Haloferax elongans sp. nov. and Haloferax mucosum sp. nov., isolated from microbial mats from Hamelin Pool, Shark Bay, Australia. Int J Syst Evol Microbiol 58, 798-802.

Bardavid, R. E., Mana, L. \& Oren, A. (2007). Haloplanus natans gen. nov., sp. nov., an extremely halophilic, gas-vacuolate archaeon isolated from Dead Sea-Red Sea water mixtures in experimental outdoor ponds. Int J Syst Evol Microbiol 57, 780-783.

Burns, D. G., Janssen, P. H., Itoh, T., Kamekura, M., Li, Z., Jensen, G., Rodríguez-Valera, F., Bolhuis, H. \& Dyall-Smith, M. L. (2007). Haloquadratum walsbyi gen. nov., sp. nov., the square haloarchaeon of Walsby, isolated from saltern crystallizers in Australia and Spain. Int J Syst Evol Microbiol 57, 387-392.

Chun, J., Lee, J.-H., Jung, Y., Kim, M., Kim, S., Kim, B. K. \& Lim, Y.-W. (2007). EzTaxon: a web-based tool for the identification of prokaryotes based on $16 \mathrm{~S}$ ribosomal RNA gene sequences. Int J Syst Evol Microbiol 57, 2259-2261.

Cui, H.-L., Lin, Z.-Y., Dong, Y., Zhou, P.-J. \& Liu, S.-J. (2007) Halorubrum litoreum sp. nov., an extremely halophilic archaeon from a solar saltern. Int J Syst Evol Microbiol 57, 2204-2206.

Cui, H.-L., Zhou, P.-J., Oren, A. \& Liu, S.-J. (2009). Intraspecific polymorphism of $16 \mathrm{~S}$ rRNA genes in two halophilic archaeal genera, Haloarcula and Halomicrobium. Extremophiles 13, 31-37.

De Ley, J., Cattoir, H. \& Reynaerts, A. (1970). The quantitative measurement of DNA hybridization from renaturation rates. Eur $J$ Biochem 12, 133-142.

Dussault, H. P. (1955). An improved technique for staining red halophilic bacteria. J Bacteriol 70, 484-485.
Dyall-Smith, M. L. (2008). The Halohandbook: protocols for haloarchaeal genetics. http://www.haloarchaea.com/resources/halohandbook

Fitch, W. M. (1971). Toward defining the course of evolution: minimum change for a specific tree topology. Syst Zool 20, 406-416.

Gonzalez, C., Gutierrez, C. \& Ramirez, C. (1978). Halobacterium vallismortis sp. nov. An amylolytic and carbohydrate-metabolizing, extremely halophilic bacterium. Can J Microbiol 24, 710-715.

Gutiérrez, C. \& González, C. (1972). Method for simultaneous detection of proteinase and esterase activities in extremely halophilic bacteria. Appl Microbiol 24, 516-517.

Gutiérrez, M. C., Castillo, A. M., Kamekura, M. \& Ventosa, A. (2008). Haloterrigena salina sp. nov., an extremely halophilic archaeon isolated from a salt lake. Int J Syst Evol Microbiol 58, 2880-2884.

Huß, V. A. R., Festl, H. \& Schleifer, K. H. (1983). Studies on the spectrophotometric determination of DNA hybridization from renaturation rates. Syst Appl Microbiol 4, 184-192.

Kates, M. (1986). In Techniques of Lipidology, 2nd revised edn, pp. 106-107, 187-188 and 251-254. Amsterdam: Elsevier.

Mesbah, M., Premachandran, U. \& Whitman, W. B. (1989). Precise measurement of the $\mathrm{G}+\mathrm{C}$ content of deoxyribonucleic acid by highperformance liquid chromatography. Int J Syst Bacteriol 39, 159-167.

Montalvo-Rodríguez, R., Vreeland, R. H., Oren, A., Kessel, M., Betancourt, C. \& López-Garriga, J. (1998). Halogeometricum borinquense gen. nov., sp. nov., a novel halophilic archaeon from Puerto Rico. Int J Syst Bacteriol 48, 1305-1312.

Ng, W.-L., Yang, C.-F., Halladay, J. T., Arora, A. \& DasSarma, S. (1995). Protocol 25. Isolation of genomic and plasmid DNAs from Halobacterium halobium. In Archaea: a Laboratory Manual: Halophiles, pp. 179-180. Edited by S. DasSarma \& E. M. Fleischmann. Cold Spring Harbor, NY: Cold Spring Harbor Laboratory.

Oren, A. (2006). The order Halobacteriales. In The Prokaryotes: a Handbook on the Biology of Bacteria, 3rd edn, vol. 3, pp. 113-164. Edited by M. Dworkin, S. Falkow, E. Rosenberg, K.-H. Schleifer \& E. Stackebrandt. New York: Springer.

Oren, A., Ventosa, A. \& Grant, W. D. (1997). Proposed minimal standards for description of new taxa in the order Halobacteriales. Int J Syst Bacteriol 47, 233-238.

Oren, A., Arahal, D. R. \& Ventosa, A. (2009). Emended descriptions of genera of the family Halobacteriaceae. Int J Syst Evol Microbiol 59, 637-642.

Saitou, N. \& Nei, M. (1987). The neighbor-joining method: a new method for reconstructing phylogenetic trees. Mol Biol Evol 4, 406-425.

Savage, K. N., Krumholz, L. R., Oren, A. \& Elshahed, M. S. (2007). Haladaptatus paucihalophilus gen. nov., sp. nov., a halophilic archaeon isolated from a low-salt, sulfide-rich spring. Int J Syst Evol Microbiol 57, 19-24.

Savage, K. N., Krumholz, L. R., Oren, A. \& Elshahed, M. S. (2008). Halosarcina pallida gen. nov., sp. nov., a halophilic archaeon from a low-salt, sulfide-rich spring. Int J Syst Evol Microbiol 58, 856-860.

Stackebrandt, E. \& Goebel, B. M. (1994). Taxonomic note: a place for DNA-DNA reassociation and $16 \mathrm{~S}$ rRNA sequence analysis in the present species definition in bacteriology. Int J Syst Bacteriol 44, 846-849.

Tamura, K., Dudley, J., Nei, M. \& Kumar, S. (2007). MEGA4: molecular evolutionary genetics analysis (MEGA) software version 4.0. Mol Biol Evol 24, 1596-1599.

Vaskovsky, V. E. \& Kostetsky, E. Y. (1968). Modified spray for the detection of phospholipids on thin-layer chromatograms. J Lipid Res 9, 396.

Xu, X.-W., Wu, Y.-H., Wang, C.-S., Oren, A., Zhou, P.-J. \& Wu, M. (2007). Haloferax larsenii sp. nov., an extremely halophilic archaeon from a solar saltern. Int J Syst Evol Microbiol 57, 717-720. 